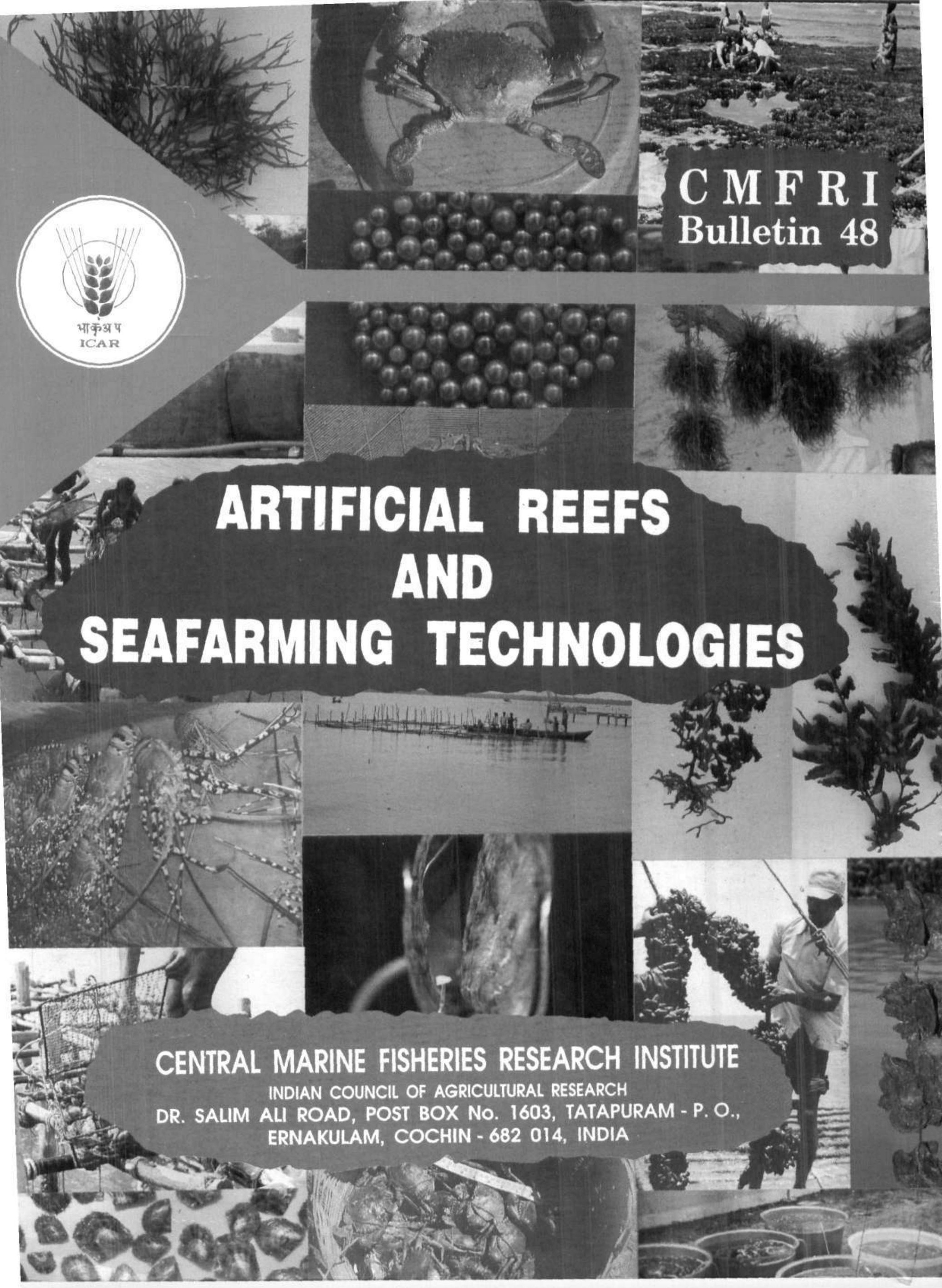




\section{M F R I \\ Bulletin 48}

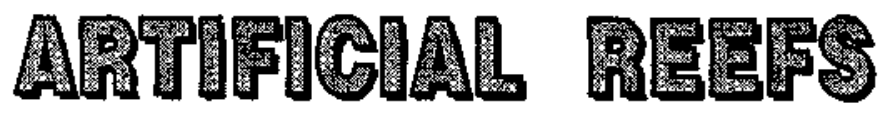 \\ A周圆

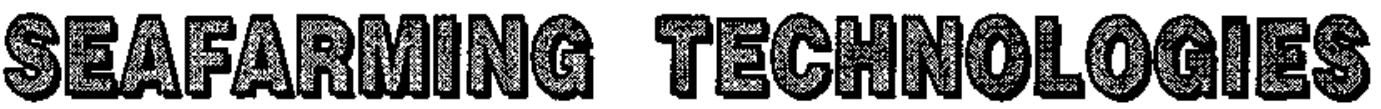

Dr. K. Rengarajan

Editor

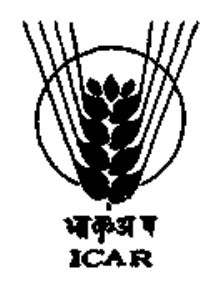

CENTRAL MARINE FISHERIES RESEARCH INSTITUTE INDIAN COUNCIL OF AGRICULTURAL RESEARCH

DR. SALIM ALI ROAD, POST BOX No. 1603, TATAPURAM - P. O., ERNAKULAM, COCHIN - 682 014, INDIA 
Bulletins are issued periodically by the Central Marine Fisheries Research Institute, Cochin to interpret current knowledge in various fields of research on marine fisheries and allied subjects in India.

(C)

Copyright reserved

Published by : Dr. M. Devaraj

Director,

Central Marine Fisheries Research Institute,

Cochin - 682014 .

Citation

Parameswaran Pillan, P. 1996. Artificial reef research in Minicoy, Lakshadweep. Bull. Cent. Mar. Fish. Res. Inst, $48: 11$ \& 12.

Cover Layout by : Dr. K. Rengarajan.

Cover Photos by : The authors.

PRINTED IN INDIA

AT PAICO PRINTING PRESS, ERNAKULAM, COCHIN - 682035 
Reprinted from the Human Organization, 1995, 54 (2) : $160-108$.

Bull. Cent. Mar. Fish. Res. Inst,, 1996, $48: 24$ - 36

7

\title{
COLLECTIVE ACTION FOR COMMON PROPERTY RESOURCE REJUVENATION : THE CASE OF PEOPLE'S ARTIFICIAL REEFS IN KERALA STATE, INDIA*
}

\author{
JOHN KURIEN
}

Centre for Development Studies, Trivandrum 695011

\begin{abstract}
This paper is about the efforts being made by communities of coastal fisherfolk in South india to build artificial reefs as a means of rejuvenating the ecosystem of their coastal waters damaged by indiscriminate trawling. These initiatives provide the basis for questioning the now influential opinions that in the case of resources in the realm of the commons, precious little will be done to save them from ruin, particularly by those individuals who enjoy access to them. It hopes to add to the accumulating evidence that collective action by the laboring masses in the developing world - peasants, fisherfolk and forest dwellers, to mention a few - to revive and rejuvenate their common pool resources calls to question the undiscriminating policy prescriptions which continue to see only "market or state" interventions to solve issues relating to environmental degradation.
\end{abstract}

There is now an impressive body of literature which documents the role played by community-level collective action in the management of common prosperity resources. To cite a few examples we have the successful anti-soil erosion and afforestation measures by the farmers of Sukhomajri in the lower Shivalik range of the Himalayas in India (Chopra et al., 1990); the peasants of Trobel, Switzerland, who have for over seven centuries managed their community-owned grazing lands (Netting, 1981); The communallymanaged irrigation systems of Illocos Norte, Philippines (Siy, 1982); the innovative self-regulation of the coastal waters by the fishermen of

John Kurien is Associate Fellow at the Center for Development Studies, Trivandrum - 695011 , Kerala State, India. He is an activist-researcher whose main interests are the political economy of fisheries development and issues relating to environment, development and collective action. This is a revised version of a paper presented at the Indo-Pacific Fishery Commission's Symposium on "Artificial Reefs and Fish Aggregation Devices as Resource Enhancement and Fisheries Maragement Tools" held in Colombo, Sri Lanka in May 1990. The author acknowledges here the efforts of John Fernandez Kadappuram and Titto D'Cruz, who through the Program for Community Organization motivated the fishermen of the region to articulate their knowledge and strive towards community erected-community-used PAR's. He was also personally associated with some of the efforts of the fishermen in their erection of PAR's and also in their collective discussions. Both proved an invaluable learning experience. The author also wishs to thank Raj Kamini Mahadevan, Dilip Menon and the anonymous reviewers of Human Organization for their helpful comments.

\footnotetext{
- Reprinted with the kind permission of the Publisher of the Human Organization, Journal of the Society for Applied Anthropology, 1995, Volume 54, Number 2, Summer 1995.
}

Alanya and Aristofersen in Turkey (Berkes, 1986); and those in Lofoten, Norway (Jentoff and Kristofersen, 1989). Some of this collection action has been endogenously structured by those who use the common property resource. Som others have taken root after appropriate intervention from "outside" led the participants to perceive some gains from collective action within the realm of their use of common property.

The resulting social institutions - some of which have existed over centuries - have evolved sets of rules which the participants understand, agree upon, and are willing to follow. It is the evolving nature of relationships between the participants, within the context of their common propexty resource, that creates new values and fresh norms, revives cultural knowledge and trust, and facilitates action towards such a desired end. James Coleman refers to such intangible institutional design as a form of social capital (Coleman, 1988).

The impressive evidence of creation of such social capital by community participation in common property resource management from around the world does not seem to have influenced mainstream policy prescription in the developed or developing countries : large sections of the academy and many in the business of state craft still emphasize "state" or "private" hegemony as the best means of governing the natural resources used in common. 
Such policy prescriptions, particularly the intervention of the state, are also premised on the contention that the victims of a ruined common property resource are the least capable of initiating action to conserve it. An eloquent critique of the foundations of such policy prescriptions together with empirical examples of collective action in governing and conserving the commons has been provided recently by Ostrom (1990).

This article proposes to take the discussion a step further. It provides a case study of "appropriators of common property resource" artisanal fishermen of India, fishing in the coastal marine waters - who have taken collective action not only to conserve their fishery resource, but also to rejuvenate it. Using the medium of artificial reefs, they not only evolved new material designs, but also crafted new institutional forms in the process of their cooperative initiatives to resuscitate the coastal marine ecosystem damaged by the use of state-sponsored and market-oriented use of inappropriate technology.

\section{The fishery and the fishing community}

India has an illustrious maritime and fishery history and features today among the world's top ten fishing nations. It has a marine coastline length of over $6,000 \mathrm{kms}$ and a vast network of rivers, lakes and backwaters that yield a fish catch of over 3.6 million tonnes (Metric tonne $=1000 \mathrm{kgs}$ or approx $2200 \mathrm{lbs}$ ). Two-thirds of this harvest is from the marine coastal waters and is netted by the half million active fishermen who belong to specific, traditional caste-bound, artisanal fishing communities who live on the geographic, economic, and social fringes of Indian socieity.

The most productive coastal marine fishery zone of India is its lower southwest coast region, comprising Kerala State and Kanyakumari District of Tamil Nadu (hereinafter referred to as "the region") (Fig. 1). It is also one of the world's most important sources of marine prawns. The annual sustainable fish yield from one $\mathrm{km}^{2}$ of these coastal waters is estimated at 35 tonnes compared to the all-India average of 13 tonnes. On this basis the maximum sustainable yield (MSY) for this region is estimated to be 380,000 tonnes per annum. The major economic species are oil sardines, mackerels and prawns.
This resource plenitude has led to the larger carrying capacity of this coastal zone and accounts for greater concentration of traditional fishing communities along this coast than else-where in India. Though the region constitutes only a little over one-tenth of the country's coastline, it is home to about a third of the active marine fishermen in India.

The $130 \mathrm{~km}$ long coastline of the Trivandrum District of Kerala State and the Kanyakumari District of Tamil Nadu is considered to be the most densely populated tract of the southwest coast both with regard to the population of fishermen and number of fishing craft. About 52,000 active fishermen reside in 90 villages along this stretch, and operate about 24,000 small traditional crafts - the majority kattumarams - made by tyng four logs of soft wood together (Fig. 1).

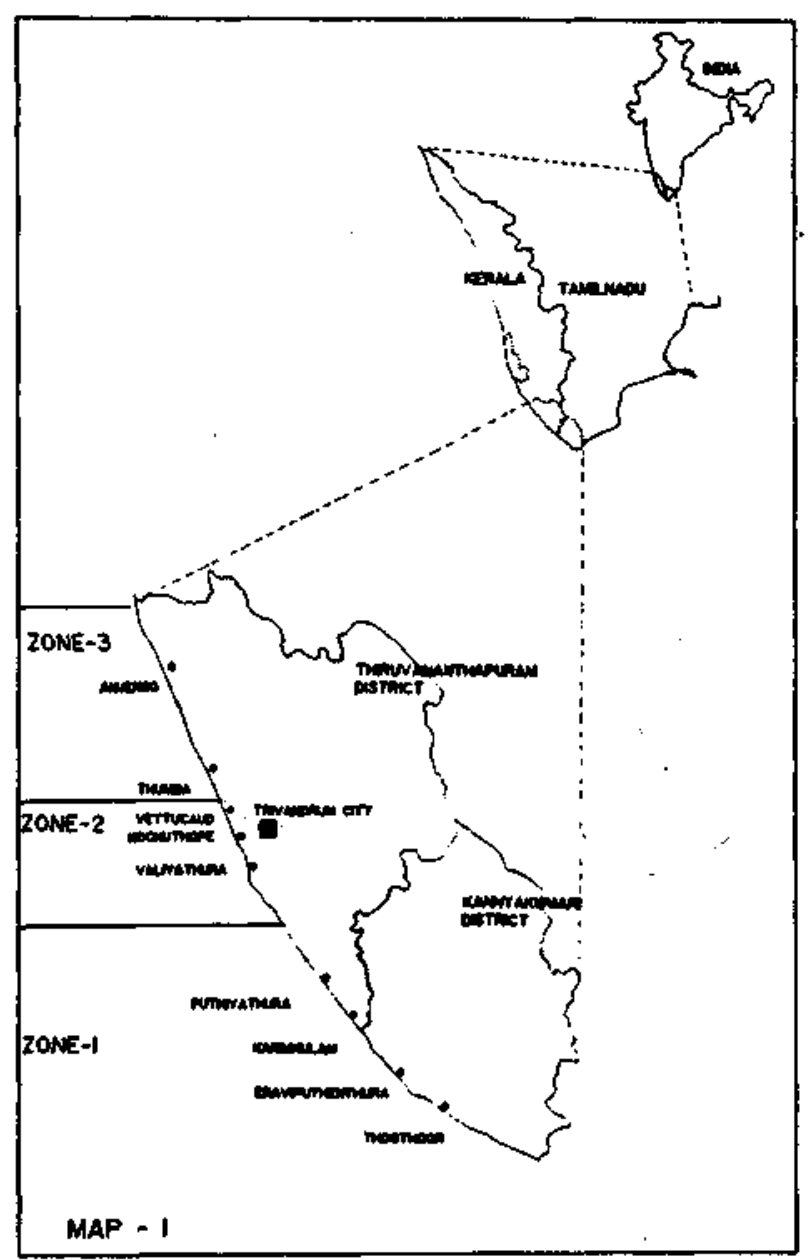

Fig. 1. Map of the stidy area. 
This area is not only famous for its dense settlement pattern, but also for the immense diversity of fish resources in its coastal waters. The assortment of passive and selective fishing gear used by the fishermen to harvest these resources is remarkable : specialized small-meshed gill nets; large multi-meshed drift nets; trammel nets; bottom-set nets and traps; boat seines; shore seines and also a variety of hook and line sets.

The fishermen of the area migrate seasonally to other fishing centers in India, with or without their fishing equipment. They have thus come to be known for their skill and daring, their intricate knowledge of the coastal waters, their navigational acumen, and their ability to fish even at the margins of the continental shelf with relatively simple technology. Their knowledge is based on a long cultural continuum of habituated practice stored in the memory and passed on by those who work. It is practical knowledge conditioned into cultural practices. At its core is an elaborate understanding of the nuances of the aquatic milieu and the behaviour patterns of living marine organisms.

\section{Early origins of the artificial reef idea}

The idea that certain types of objects when dropped in the coastal waters tend to attract fish has undergone considerable evolution among the fishermen of the region. They refer to all such sunken objects as kritrima paar (artificial reefs).

Artificial reefs are man-made or natural objects specifically placed in the coastal waters to attract fish, provide or improve fish or shellfish habitat, and increase fish biomass locally. Their design can range from haphazardly lowered local scrap materials to modern Japanese-style structures in the form of highly sophisticated modules built of concrete, fibreglass, or steel ${ }^{1}$.

Reconstructing from the oral tradition of the older fishermen we provide a brief history of the artificial reefs in the area. It is said that there was an age old practice, among the fishermen of the area who operated the shore-seine, of dumping rocks fastened with coconut fronds into the near shore sea within depths of 5 to 10 metres. Fish tended to aggregate over and around these rocks and were more easily netted by the shore-seines.
Large sunken structures also proved useful in serving the same purpose. It was known that a ship had sunk off the village of Anjengo during the Second World War because the local fishermen had rescued some of its crew. In 1949 a hook fisherman discovered the wreck at a depth of $\mathbf{5 0}$ metres. He was amazed by the high hooking rate over the limited area'. News of this new fishing spot spread quickly by word of mouth. Expert hook fishermen from the more densely populated southern villages of the area swamped the area and achieved greater success in fishing over the wreck by using artificial bait. The use of artificial bait was new to the fishermen of Anjengo and initially they opposed $\mathrm{it}^{3}$. But within a brief period the southerners settled down in Anjengo by marrying into the community". Soon, the use of artificial bait to fish over the kappal paar (ship reef) gained wide-spread acceptance in the village.

During the early forties, a ship berthed at the Valiyathura Pier near Trivandrum city lost its anchors in a storm. Only one was immediately recovered from the sea bottom. The other anchor was found only a decade later when a hook fisherman got his line entangled in it. His loss was temporary because it was compensated by his simultaneous discovery of a rich fishing spot around the nanguram paar (anchor reef).

The early practice of dumping rocks with coconut fronds in the shore-seine fishing grounds and the discovery of the rich fishing spots atop sunken structures in deeper waters provided the basis for conscious attempts to erect artificial reefs in deeper waters.

The first examples of such artificial reefs date back to the early 1950 s in the villages where natural reefs existed and where there was a tradition of hook and line fishing. The best example of such a reef was the one erected in 1955 in Puthiyathura. The hook and line fishermen of Puthiyathura had been fishing over the natural reefs found close to the shore ( $2.5 \mathrm{~km}$ away) at a depth of $40 \mathrm{~m}$. Over time they observed that fishermen from the neighbouring village of Karimkulam - also fishing off a natural reef at about the same depth - got better harvests. The only difference that they observed between the reefs was that the one off Karimkulam was higher than theirs. This led them to try ways and means 
of raising the height of their own reef. They dumped granite stones piled on the beach to form anti-erosion sea-walls on the existing natural reef thus raising its height by about a metre. The fishermen observed that six months later their efforts paid off in the form of higher hooking rates.

Another early attempt in 1957 was made in Eraviputhenthura. The hook fishermen of this village and a favourite fishing spot about $1.5 \mathrm{~km}$ off the coast at a depth of $22 \mathrm{~m}$. The sea bottom here had a clay substratum and the larger concentration of fish observed there was attributed mainly to this. In their village the panchayat (local administration) authorities had used large concrete rings ( $3 \mathrm{~m}$ in diameter and $0.5 \mathrm{~m}$ high) to build a community well. One of the unused concrete rings remained on the beach. The fishermen got together, transported this ring on their kattumarams to their favourite fishing spot and dropped it there. This was the first known example of an external pre-fabricated structure being used in a known. fishing spot as an artificial reef. The new reef was christened Vatta paar (ring reef).

\section{Decline of artificial reef construction}

For almost a quarter of a century after the late 1950 s little was heard of more attempts to create reefs. Several reefs however, were formed by accident and these continued to provide occasional fishing spots ${ }^{5}$. For a while, they generally provided to be good fishing grounds, but then ceased to be productive.

The sudden loss of interest in reefs can be largely attributed to the new fishery development strategies of the $1960 \mathrm{~s}$. The importance given to the fishery sector changed rather dramatically. India was facing an acute foreign exchange crisis in the 1960 s and every effort had to be made to increase exports. New harvesting technologies like bottom trawling were promoted in a big way by the government to cash in on the prawn boom following the marked increase in prawn prices in the international markets ${ }^{6}$. The coastal waters once the eclusive preserve of traditional fishing communities who viewed the sea as their community asset - became a virtual open access resource to anyone who could afford to make the necessary investments in craft and gear.
The new harvesting technologies and the prawn export processing industry became the domain of a new class of capitalist entrepreneurs. They employed a small section of male workers from traditional fishing communities on the trawlers and women workers in the processing plants. The vast majority of the active fishermen continued their artisanal pursuits with the only major changes being the use of nylon for fabricating their nets and higher price for their fish.

Fishing effort and fish harvests increased substantially. In Kerala State, from a level of 286,000 tonnes in 1961, the fish harvest increased to 337,000 in 1965 and peaked at 445,000 tonnes (significantly above MSY) in 1971 . Since prawns were mainly found in the inshore coastal waters there was virtually no increase in the fishing area following the introduction of the trawlers. A greater and more powerful fishing fleet was continuously harvesting the same stock of fish in a small area of the coastal sea. This resulted in a conflict over space and product with the large number of artisanal fishermen. From 1975, despite rising investments (or rather because of it) the . harvests began to fall below the MSY level indicating that the resource system as a whole was adversely affected. The significant drop in productivity (in physical and value terms) resulted in lower income levels despite rising fish prices. A crisis was in the making (Table 1).

\begin{tabular}{|c|c|c|c|c|c|}
\hline & 1961 & 1965 & 1971 & 1975 & 198 \\
\hline Fish Harvest (000 tonnes) & 286 & 339 & 445 & 420 & 274 \\
\hline $\begin{array}{l}\text { Harvest as } \% \text { of MSY } \\
(\mathrm{MSY}=380,000 \mathrm{t})\end{array}$ & 7 & 89 & 117 & 110 & 72 \\
\hline $\begin{array}{l}\text { Price of fish (Rs/t) } \\
\text { Value of harvest (Rs. mn }\end{array}$ & n) 120 & 200 & 660 & 1760 & 2000 \\
\hline Current Prices & 35 & 68 & 293 & 740 & 548 \\
\hline Constant Prices (60-61) & 35 & 48 & 138 & 197 & 144 \\
\hline $\begin{array}{l}\text { Active Fishermen }(000) 3 \\
\text { Fishing Crafts }\end{array}$ & 80.7 & 88.6 & 101.9 & 111.6 & 127.9 \\
\hline Non-Mechanized & \multicolumn{2}{|c|}{20667209200} & 21718 & 25100 & 26271 \\
\hline Mechanized & 152 & 501 & 1780 & 2105 & 3038 \\
\hline \multicolumn{6}{|l|}{ Productivity per annum } \\
\hline Physical (kg/worker) & 3540 & 3820 & 4370 & 3760 & 2140 \\
\hline Value (Rs/wik-current) & 430 & 770 & 2900 & 6600 & 4300 \\
\hline (Rs/wkr-const) & 430 & 550 & 1370 & 1760 & 1134 \\
\hline
\end{tabular}

Source : Kurien, 1987 
The year 1979 witnessed the beginning of a socio-ecological movement spearheaded by the artisanal fishermen of the region, with the assistance of several social activists, formed a trade union. The union presented three major demands to the state authorities: (a) a total ban of trawl fishing during the monsoon period of June, July and August which was the breeding season for many species of fish; (b) reinstating the in-shore coastal commons to the artisanal fishermen in which trawlers would be totally prohibited; and (c) a greater share of assistance to the artisanal fishermen in the fishery development budget of the State (Kurien, 1992).

By 1983, this movement had attained the dimensions of a major political force in the region. In a preliminary democracy with numerous coastal constituencies, a restive fishing community was no solace for politicians, irrespective of their political color. Regardless of whether they were in or out of power, they began to take the fishermen's demands seriously.

In 1984, the second and third demands of the fishermen were conceded by the government. Legislation to demarcate and regulate the coastal waters was enacted and a police force to enforce these measures was set up. The emphasis on promoting prawn exports using State finances was relegated and the funds were earmarked for investment which would directly benefit the artisanal fishermen. A big push was given to upgrading their harvesting technology through the supply of outboard engines, beach landing crafts and new fishing gear. Welfare measures for artisanal fishermen and their families were also increased significantly.

The demand for a total monsoon trawl ban was conceded only in 1989 after three scientific commissions had studied the matter following the fishermen's refusal to compromise on this issue.

The importance of this socio-ecological movement was that it was the fishermen's first collective macro-initiative to re-establish their historical rights of exclusive access to the inshore coastal waters. In the words of an artisanal fishermen's union leader, on his sixth day of an indefinite fast before the government secretariat demanding greater regulation of the coastal waters: "Our struggle is to ensure a future - for us and the fish".

\section{Resurgence of the artificial reef idea}

The conflicts and impasse in the current pattern of fisheries development, the ecological crisis and the macro-level political mobilization around it, brougt renewed vigor to the search for alternatives.

The gains of the fishermen's movement in pressuring the State to legally recognize their traditional rights over the coastal commons was no small achievement. However, neither the State nor the unions had the enforcement structure necessary to protect the claims to the coastal commons. The costs of such an enterprise would have been prohibitive. An important and practical way to overcome this on, the part of the fishermen, was to initiate steps to define and protect the coastal zone within limits of individual fishing communities. The village-level measures taken by artisanal fishermen to achieve this, led to violent clashes with the trawlers, litigation by the trawler lobby, and accusations from the State that the fishermen were taking the law into their own hands.

The search for alternatives to rejuvenate their coastal commons was, however, on a different plane. At the village level, one important manifestation of this search was in the form of gramakuttoms (village gatherings) at which fishermen and social activists discussed the need to revive, strengthen, and enhance their cultural beliefs and knowledge about fish and the natureprocesses in the sea.

These discussions highlighted the fishermen had a strong conservationist ethic towards the fishery resource. They had a keen awareness and knowledge of the totality of the aquatic ecosystem and viewed Kadalamma (mother ocean) as their community asset and a life-giving system rather than a hunting ground. Bringing ruin to her, individually or collectively, was something they could not comprehend.

Hook and line fishermen from the Trivandrum District were in the forefront of the 
village movement to help Kadalamma rejuvenate herself. Their success in fishing had depended exclusively on their encyclopedic knowledge of the natural reefs, sand banks in the sea and other fishing spots. They were the first to be affected by the damage to the demersal ecosystem caused by incessant trawling. Though they were victims of a tragedy of the coastal commons, they did not become strait-jacketed prisoners when faced with this dilemma.

Fishermen's knowledge about reefs : Discussions with the younger fishermen illustrated very clearly that although two decades had elapsed since artificial reefs were constructed, knowledge about the reefsea-fish interactions had been passed down to them from the older generation and kept alive by their own practice of fishing over them. There was a holism about their understanding which stemmed from their concern with the whole resource system rather than just the fish in it.

Fishermen consider reefs as an important basis for ecosystem rejuvenation. This association is premised on their understanding that underwater structures in the sea cater to the adisthana avasyangal (basic needs) of fish; their need to feed; their strong desire for protection, rest, and shade; and their urge to breed.

Consequently, for an artificial reef to be a source of food to fish, the kind of materials used to build it gained importance. The materials used should be those on which benthic vegetation would aggregate quickly thereby ensuring adequate food supplies. The artificial reef needs to be erected in areas where the sea bottom is naturally productive.

To serve the needs of protection, rest and shade for fish, the structure and the position of the artificial reef are determining factors. Only an artificial reef of sufficient height will provide shade. Solid structures are not conducive for protection and rest as they do not provide hiding places from predators. If fish are to make artificial reefs their breeding grounds, then the prerequisites of food and protection become imperative.

For fishermen to be able to catch the fish which use the artificial reefs in such a wide variety of ways, the reefs should be aligned on the seabed in the east-west direction. Given the north-south direction of littoral current in the region, this is the best alignment to ensure that the maximum number of fishermen can fish over an artificial reef at any given time without getting their hooks entangled. They have also learned that artificial reefs shoud be located in the "fish channel" - a path which was identified as being between 25 and $50 \mathrm{~m}$ depth in the inshore sea. Referring to the way this total understanding of fish behaviour helped to induce fish into the artificial reefs, one fisherman remarked: "The fish teaches us and then we teach the fish (a lesson!)".

Sharing knowledge : The process of sharing the knowledge which they had accumulated over the years was achieved by creating unique possibilities for inter-village discussions. The forum for this was provided by the Program for Community Organization (PCO), a voluntary organization initiated by this author and a few other social activists - which had been in close contact with these fishing communities for over two decades since the early $1960 \mathrm{~s}$.

In the initial years, the work of the PCO was based on its association with groups of fishermen and their families in individual villages in the area. Land based issues like cooperative marketing of fish as well as employment and training for the youth were the focus of activities.

The crisis in the fishery in the late 1970s changed all this. The village specific "land-based" approach gave way to a more generalized "seabased" strategy for mobilization and awareness creation among the active fishermen of the area as a whole. The focus shifted towards analyzing the various facets of the relationships between fishworkers and the sea, the ways and means by which these bonds were disrupted as a result of state-sponsored fisheries development, and the manner in which the links could be strengthened.

The first important outcome of this change of orientation was the cadre-formation training and movement-oriented research backup provided to the newly formed fishermen's union referred to above. The second, close on the heels of the first, was the support in the search for micro-level alternatives for "greening" the coastal commons. 
The exchange of information regarding natural and artificial reefs was part of the second strategy. The initial attempt by the PCO was to encourage fishermen to articulate the slowly disappearing oral traditions of their knowledge systems so that it could be documented, and, where possible, refined and complemented with the knowledge of modern science.

The pedagogy used for this process included arranging for the older and more experienced fishermen from villages with pre- 1960 experience of fishing over reefs to share their knowledge with others. One revelation during these sharing sessions was the difficulty of fishermen in expressing physical reality on a two-dimensional scale using the blackboard. This difficulty was overcome by their own suggestion that it would be easier for them to explain the science of reef building using a small glass fish-tank or pond using stones and leaves.

These animated sessions, attended by fishermen from several villages in the area, laid the bare foundations for a people's science movement. It also served to foster a new group of leaders vastly different from those who spearheaded the unions. Charisma, public-speaking talents, and political acumen got low priority; fishing skills and a hands-on grasp of technical details and community organization skills became more important.

The need for a better understanding of natural processes that take place underwater around an artificial reef highlighted the scope for a far greater degree of collaboration between coastal fishermen, marine biologists, oceanographers, and other scientific personnel. It revealed the exciting possibilities of undertaking what Norgaard referred to as a "coevolutionary development process" of the two knowledge systems. (Norgaard, 1984, Kurien, 1987).

Such discussions, arranged by the PCO, gave a big impetus to the learning process. They also revealed the sharp differences in the approach of scientists and experienced fishermen towards the marine ecosystem. While the former were preoccupied with their ability to make precise descriptions about fish behaviour and the nature of the sea, the latter were more adept at isolating the crucial interrelations which aided their ability to catch fish.

Promoting true dialogue was a slow and not too successful venture. For the fishermen, these sessions provided an opportunity to widen their horizons and provided the opportunity of getting to know what went on around them and also in other parts of the world vis-á-vis artificial reefs.

\section{Towards People's Artificial Reefs (PARs)}

The renewed initiatives among fishermen to erect artificial reefs needs to be situated against this background. Several groups of fishermen from as many as 22 villages in the area decided to take creative, collective action to erect reefs in the coastal waters off their villages. These actions needed to be viewed as the micro-level expression of their historic macro-level socio-ecological movement. We have termed the reefs erected in this process as "people's artificial reefs" or PARs.

During the years 1979-1989, the pace at which PARs were erected increased substantially (Table 2). The stretch of coastline where PARs have been erected can be further divided into three zones with the city of Trivandrum, the capital of Kerala State, as the reference point (Fig. 1 and Table 3).

TABLE 2. People's Artificial Reefs erected in Trivandrum and Kanyakumari

Before $1960 \quad 1979-83 \quad 1984-1989$.

$\begin{array}{llll}\text { No. of PARs erected } & 2 & 9 & 21\end{array}$

Source: Adopted from Kadappuram, 1989

TABLE 3. Percentage distribution of PARs along the coast

\begin{tabular}{llcc}
\hline Area & & Pre-1960 & Post-1979 \\
\hline Zone 1 & $\begin{array}{l}\text { Villages south of } \\
\text { Trivandrum City }\end{array}$ & 100 & 40 \\
Zone 2 & $\begin{array}{l}\text { Villages around } \\
\text { Trivandrum City }\end{array}$ & - & 50 \\
Zone 3 & $\begin{array}{l}\text { Villages north of } \\
\text { Trivandrum City }\end{array}$ & - & 10 \\
Source: Adapted from Kadappura, 1989 &
\end{tabular}

The PARs erected during this period witnessed changes both in relation to the materials 
used and the institutional processes associated with the erection of and access to the PARs.

Changing materials : The "first generation" reefs erected before 1960 used materials available at the village which the fishermen could obtain without money. This "whatever-you-can-get" approach to collecting materials to erect reefs continued until the 1980s. The fishermen of Eraviputhenthura who were the first to use a pre-fabricated structure (cement well ring) in 1957 erected their first PAR in 1980 with the large unused iron wheel of a damaged road roller that was abandoned in the village. In Valiyathura an unused telephone post was used in 1983. However, with more organized and widespread efforts to build PARs, it was unlikely that such an approach could continue for long.

In the "second generation" PARs erected between 1984-86, it was noticed that while granite stones wrapped in coconut fronds remained the main component, three more important additional items were widely used: large rocks packed in monofilament net bags; the screw-pine plant: and cement well rings. All these items had to be specially ordered or collected specifically for the purpose and paid.

After 1986 there was a further spurt of changes. The use of old automobile tires tied to cement rings was tried out by the fishermen in Valiyathura. In Thoothoor, the granite stones were painted red before they were transported to the sea. Along with this came the measures taken to protect the PARs from being covered by fishing nets. Rings with built-in-hooks, anchors and concrete pillars placed at the four corners of the PAR structure were examples of the measures taken by the fishermen.

Changing Institutional Forms : The discussions about materials and designs was accompanied by the concerns about the micro-level institutional processes and forms to be adopted in erecting reefs and having access to them.

The information which we have of the pre1960 reefs (in Zone 1 ) indicates that the erection was the result of the initiative of a small group of fishermen in the villages community. There were no perceived "private costs" to the group : the materials used were obtained free of cost and the labor involved in erecting the reef considered shramadan (voluntary labor). As a result the "promoters" of the reef were not overtly preoccupied with questions about property rights or private returns.

In the post- 1980 period we observe a quiet accretion of social capital in the form of institutional designs associated with the PARs. For a more analytical appreciation of these changes it may be useful to consider two fecets of the activity: (1) the initiatives for erecting PARs and (2) the claims for access to the PARs.

Initiatives for erecting reefs came from four quarters: individuals in the village, groups of fishermen within a village, the whole village community, and external agencies. These were not mutually exclusive type of initiatives. For example, certain leading individuals may play crucial role in the initiatives taken by a specific group of fishermen to erect a PAR. Altematively, an external agency - e.g. an NGO, the church/ temple, - may financially or otherwise assist the whole village community in erecting a reef. By and large, these efforts were motivated by the concern to rejuvenate the "resource system" of the damaged coastal commons and thus rejuvenate the fish stocks.

The claims for access to the PARs came from two sources: a group in the village community or the whole village community. These access claims were motivated by differing understandings about the rights of appropriating "resource units" of fish from the PARs.

We shall enumerate below five "erectionaccess" combinations which have been observed in the post- 1980 period. At present, some combinations co-exist and some of them are likely to emerge as dominant forms.

Individual Erection - Group Access. One of the first post- 1980 reefs was erected in 1983 by an exserviceman from the fishing community in the village Valiyathura (Zone 2). He organized the erection of a reef partly using material freely available on the beach (stumps of coconuts, etc.) and also by arranging for the purchase of granite, cement rings, etc. This reef came to be known 
after him as Ouseph Paar (Ouseph's reef). The total cash investment was estimated to be about Rs. $1000 /$ - which Ouseph claims to have raised by pledging his wife's gold ornaments. He hoped to recover this investment by collecting a rent from the fishermen who were accorded access to the reef by him. The reef became productive in about three months and became known as a good fishing spot. Due to the difficulty of monitoring and preventing free access to the reef, Ouseph's hopes of profit were only partially realized.

Group Erection - Group Access. Ouseph Paar became the inspiration for fishermen to consider taking their own collective initiatives to erect reefs as the means of rejuvenating the coastal commons and enhancing their fish harvests. Small groups in the villages joined together, collected equal shares, and erected reefs.

Initially, these small group initiatives were restricted to the villages around Trivandrum City (Zone 2), where hook fishermen were in a minority (Fig. 1). In 1984 the fishermen of Kochuthope, a village just north of Valiyathura erected a PAR which cost them Rs. 6000 . Initially only the 100 hook and line fishermen who contributed to the erection had access rights to the PAR. Subsequently, when the PAR was built-up again, the membership was raised to 300 . Their collective experience of restricting the use of the PAR to the members who contributed funds for its erection was fairly successful.

There was a spurt in the number of such "group erection - group access" PARs in the Zone 2 villages during the years 1984-85. The PARs were located just outside range of the shore-seine operations (at about $15 \mathrm{~m}$ depth) which was about 1.5 to $2.0 \mathrm{kms}$ from the shore and just within keen eye-shot.

The fishermen of Zone 2 enumerated five distinct advantages of this location: (a) it prevented conflict with shore-seine operators; (b) it allowed easier monitoring of the PAR for "poachers," mainly from the neighboring villages; (c) it was within rowing distance, thus dispensing with the need for mechanical propulsion to reach the PAR and thereby reducing the costs of fishing; (d) proximity also made the PAR accessible to the older and the very young fishermen; and (e) since the reef fish were fresh and brought quicker to the shore they fetched a higher shore price.

At no stage during these years (1984-87) were PARs considered to be providing a major source of the fish harvests. However, the positive experience surrounding the erection of and access to PARs resulted in a favorable disposition towards enhancing the scope and dimensions of such group initiatives.

Group and Extemal Agency Erection - Group Access. In early 1988 , the fishermen of Valiyathura, who were members of a village-level cooperative part of the apex organization called the South Indian Federation of Fishermen Societies (SIFFS), decided to erect a reef. They formed a group of 100 members with each one contributing Rs. 100 towards the cost of reef material. They approached SIFFS for a grant of Rs. 10,000. The amount was granted and the SIFFS also took the initiative to arrange for fishery scientists to be associated with the erection as well as the monitoring of the biological aspects of this PAR.

The nature of access rights did not materially affect the activities of the scientists who were monitoring the biological changes that were taking place underwater. However, to assess the economic viability of PARs - a task which SIFFS intended to do - restricted access rights would make the task much easier. The concept of "group erection-group access" was therefore supported by SIFFS on the grounds that it was easier to monitor such reefs to establish their economic viability since the fish harvest is restricted to a well defined group.

Group Erection - Community Access. Our inquiries reveal that at about the same time as the fishermen in the villages around Trivandrum City were erecting their "group erection - group access" PARs, fishermen in the villages south of Trivandrum (Zone 1) where hook fishing predominated and where natural reefs were once in abundance, were erecting PARs adopting what they termed the utsava shylee (festival approach).

The erection of and access to these PARs was analogous to the funding and celebration of a village festival. For village festivals, funds are collected from all the households in the village on 
the basis of a "whatever-each-one-can-give-happily" approach. Contributions could be in cash or kind. The actual initiative and hard work of organizing the festival is undertaken by a core group (a festival committee) whose primary gain is social recognition. Any number of volunteers are accommodated. While the grandeur of the festival is proportionate to the total funds raised, access to the fun of the festival day is open to all in the community irrespective of their contribution.

The analogy can be fully extended to the PARs erected by fishermen in Zone 1 . These PARs are assets financed by voluntary contributions of the entire households in the village; erected by a group of able-bodied, young fishermen, with the access to the PAR being open to the whole village community.

Community Erection - Community Access. It was during discussions at the $\mathrm{PCO}$ that fishermen from the southern villages (Zone 1) heard about the system of "group access claims" to PARs erected by groups of fishermen in the villages around Trivandrum (Zone 2). They were astonished and remarked: "You don't show your natrowness at a village festival or at sea. Both are for all." A very animated discussion followed in which the implications of the philosophy of stewardship of natural resources was raised. They were of the opinion, that as children of the sea and as those who know the secrets of the sea, such a narrow and partisan approach was not warranted among themselves.

The fishermen from the southern villages (Zone 1) suggested that while access to the PARs should be open to all, certain community agreements need to be evolved to restrict fishing effort by individuals. For example, a limit should be placed on the number and size of hooks. The use of lights to fish over the reef at night should be prohibited. Only one member of a household should fish at the PAR. These would ensure a more equitable distribution of the catch. Community sanctions for those who violated these norms were appropriated.

These inter village discussions resulted in a self-critical review of the other approaches. Despite some initial resistance and skepticism - backed also by reservations to this approach from SIFFS - the fishermen in Zone 2 made a quiet transition of community access to PARs. The discussions transformed the situation from one where village communities took isolated decisions to one where the pros and cons of seemingly appropriate decisions could be tested against the merits of the more rewarding experiences of others.

The most recent initiative (1991) to create a PAR by the fishermen of the village of Thumba (for the first time in Zone 3 ) bears witness to the effectiveness of committed information exchange about meaningful experiences. In true festival style the whole community of Thumba was motivated to raise funds to erect a PAR which they claimed would help to rejuvenate a natural reef which was recently destroyed by the indiscriminate fishing of a large fleet of trawlers. They formed a sahodara samajan (brotherhood fraternity) in which one member from each of the fishermen households in the village was given membership. This was a means of formalizing total community participation in the complete ventue. The sahodara samajam elected a "works committee" which would be responsible for erecting the PAR, deciding on the norms/restrictions on access, and for settling conflicts should they arise. Every household made a financial contribution. This fund was matched by an equal grant from their church? . Some technical assistance was obtained from the PCO on the appropriate shapes of the specially designed concrete structures to be used.

From the above description of the changing institutional forms we can discern a concerted movement towards greater community involvement in the erection and access to PARs. Sharing of experiences through a committed exchange of information facilitated largely by an NGO led to a steady process of accretion of institutional social capital. Implicit in this has been both a collective learning and self transformation process for large sections of the community of fishermen. The result has been the growing support for an institutionalchoice which spreads both the costs and the benefits more evenly within the community.

These changing institutional forms challenge the influential predictions that only state or market solutions can allocate and protect common 
resources. They also call to question the assumption that those who are caught in a "commons dilemma" would rarely invest time and money in the design and supply of institutions to conserve it.

The initiatives of the fishermen of the region also illustrate that people who have a very intimate association with natural resources as a source of livelihood, given the appropriate circumstances, can empower themselves to go beyond macro-level collective action aimed at conserving resources to micro-level initiatives for improving and rejuvenating them.

\section{Enter the state}

Policy makers, government bureaucrats, and scientists were unaware of the growing importance and members of PARs until this fact was brought to their notice by the Program for Community Organization in 1987. When first appraised of the matter, they viewed these initiatives as quaint since they did not fit into the usual pattern of development and management strategies initiated to meet the crisis of overfishing of the coastal commons.

Having been in the past decade preoccupied with ways and means of getting the maximum amount of fish out of the sea with a minimum of social conflict and law and order problems, it was not surprising that they initially considered the "throwing of granite into the sea" to be a waste of time, materials, and money. Measures such as providing outboard engines or better craft to artisanal fishermen to fish in deeper waters and putting into action a marine police force to regulate fishing in the coastal waters were more in line with their concerns.

With the spread of the idea of PARs among the fishermen and the scientists, policy makers have begun to take cognizance of the matter. Initiatives of the fishermen along the lower east coast of India (Tamil Nadu) to build reefs and the role of NGOs specializing in rural technology in assisting their efforts has prompted the Department of Science and Technology of the Government of India to initiate a national program on artificial reefs. The purview of the program has now been extended to include the lower southwest coast region.
As a pilot project of this national program a prefabricated reef was placed in the coastal waters of the district of Alleppey in Kerala State. This was done with much official fanfare, but no participation from the local fishing community. The initiative was publicized as a resource conservation measure. There were to be no restrictions on access to the reef.

Unfortunately, the last one heard of the reef was also on the day of the official function. Fishermen of this district who have for decades used encircling nets to harvest large shoals of pelagic fish (which have no need for a reef habitat) have never known the use of reefs. Consequently the estimated Rs. 50,000 invested in this Statesponsored project was really a misplaced investment in every sense of the term.

\section{The future of PARs: New meanings, new directions}

The changes in materials, designs, and institutional forms have resulted in PARs attaining a wide range of "meanings" to the artisanal fishermen.

PARs are no longer just the collective effort of "throwing granite into the sea". They have become a symbol of the joint efforts for "greening the sea". They have become a symbol of the joint efforts for greening the sea". They have become the artifact around which fishermen can make creative use of their accumulated, transgenerational knowledge about the aquatic milieu and the behavior of fish.

PARs are also seen as the appropriate physical structures for a fencing of their exclusive fishing zone against the incursion of trawlers. PARs are the rallying point for collective action in evolving institutional processes and institutional forms for coastal resource rejuvenation.

While our description of the changing institutional forms highlights a noticeable convergence towards community access to PARs, the initiatives to erect the PARs are likely to receive the support of external agencies in the future. If the present level of investments can be maintained (on average, about Rs. 10000-15000 per PAR), community initiatives to erect PARs are likely to continue. Since community erection is closely 
associated with community access, an open question still remains: Will the coastal commons in the long run become "privatized" by village communities with differing economic endowments and fishing skills?

On the other hand, the success of PARs is creating a growing appreciation among the fishermen of the need for bigger and better designed physical structures for PARs - e.g. specially designed concrete structures. This is creating a latent demand for a greater level of financial investment in artificial reefs beyond the capacity of local village communities. The opportunity for more organized state involvement becomes an imminent possibility.

State investment will foster the negation of community access and favour open access for all active fishermen. It will also tend to "standardize" artificial reef construction taking out from if the "people's science" element and the popular, decentralized participation in creating this social asset. People would lose their autonomy and become passive recipients of the benevolence of a central authority. The values associated with PARs as concrete expressions of the people's will and resolve to nature a damaged ecosystem will tend to get lost in the euphoria of reefs as a means of enhancing fish harvests and quick profits'.

This likely divergence in the future intiatives in erection of and access to PARs point to "higher order" dilemmas and choices of the future (Ostrom, 1990). The course that emerges will depend on a multiplicity of factors. Most important in this will be the manner in which these micro-level initiatives mesh into the larger macrolevel actions which attempt at pressuring the State to redefine its power equations with the fishing community.

\section{Lessons in collective action}

The actions of the fishermen of the area in erecting PARs questions the conclusion that people confronted with a "Hardinian tragedy" of a ruined commons, will in accordance to Olson, not join hands for collective action unless coerced to do so. It also raises the issue about the assumption of the prisoner's dilemma game : that there cannot be any change in the structure of the game.
By examining the brief history of PARs we see that once those caught in a dilemma meet, discuss, exchange views, and learn from each other, it is unlikely that they will retain the status quo structures. They evolve new learning, new institutions and new trust among themselvesattributes which contemporary theories of collective action are only beginning to address.

We have observed how the resurgence of reef building, in the wake of the marine resource crisis, has also brought with it the reaffirmation of the community's responsibility to nurture the resource-system which is the basis of their survival. It has also provided a new, collective motivation for them to articulate, sharpen, and expand their knowledge base by greater interaction between themselves and with scientists and social activists. The resolve to build PARs has also provided fresh foundations for the spontaneous growth of new village leadership and widespread community participation. All of these are essential ingredients for sustainable collective action.

There is no claim that PAR building will make any substantial contribution to healing the wounds inflicted on the coastal ecosystem of the area. Nor can it be said that the future of these small-scale fishing communities and the common property resource which they consider to be their inheritance depend overwhelmingly on the success or failure of PARs as technological artifacts.

If an alternative development paradigm is to emerge, with sustainability of the coastal resource system at its heart, then the key to the future will be cultural, socio-economic and political empowerment, and even more importantly the social capital of institutions crafted during the collective action.

\section{Notes}

\footnotetext{
"The extent to which artificial reefs increase fish biomass or redistribute existing stocks of fish is not clear. However, even if they do not substantially increase fish production, they can be used as effective fisheries management tools. The increased standing fish crop around artificial reefs reduces fishing effort and, therefore, saves time and fuel. Fishermen in developing countries often must limit their efforts because of high fuel costs. Furthermore, artificial reefs can be used to create fishing grounds for artisanal fishermen who use traps and hook and line gear (Bostid, 1988).
} 
${ }^{2}$ Using their depth gauging plumb-lines the fishermen have estimated the wreck to measure 50 metres in length and 45 metres in width. The top of the wreck was just 15 metres below the surface. This spot was until recently (until 1985) considered to be one of the major fishing grounds of the region. Fishermen say that ton many drift and gill-nets which got entangled to it have wrapped around the top of the wreck and reduced its productivity.

${ }^{3}$ In the oral tradition of the village there is a couplet which eludes to this discovery and the use of artificial bait: "Sukkuruppan kandupidicha kappal paar/Irayillathe meen pidichu thekken maar" (Translation) : Sukkuruppan discovered the shipwreck/(But the) Southerners fished over it without live bait. tradition.

"Fishing communities of this region follow a matrilocal

${ }^{3}$ The most interesting examples are that of the spent rocket heads (fired from the equatorial rocket launching station, Trivandrum) that dropped into the sea. Initially the authorities provided a compensation to fishermen who "discovered" these - when their nets got entangled on them and partially destroyed in the process. Soon the fishermen coserved that the rocket heads became good fish aggregating devices.

"International prawn prices began to increase with the stoppage of Chinese exports after 1949 and the rising per capita incomes in Japan. Prawns were not a preferred seafood in this region. It commanded a price much lower than that of other species of fish until this export boom.

${ }^{7}$ The funds at the command of the church are completely raised by contributions from the daily earnings of the fishermen of the community. Such funds are controlled by the priest and a committee comprised largely of non-fishermen from the community. Chunch funds are normally utilized for building/ extending church structures and for religious festivities. Against this background, the contribution for an occupational purpose attains great significance became of its potential demonstration effect along the coast.

${ }^{8}$ This is likely to be an imminent possibility given the keen observation by fishermen that cuttlefish (Sepia pharonis) which has a big export demand, spawn in the PARs. Whether fish other than specific "reef fishes" breed on artificial reefs still seems an unsettled issue among American and Japanese scientists. The former continue to debate whether artificial reefs actually increase productivity or merely attract and concentrate organisms from surrounding area. Japanese scientists generally have little doubt that artificial reefs, when properly designed, sited and placed can be used to increase the productivity of desired species. (Sheeby, 1982).

\section{References cited}

BERKES, F. 1986. "Local-level management and the commons problem : A comparative study of the Turkish Coastal Fisheries." Marine Policy, 10 : 215-229.

BosTD, 1988. Fisheries Technologest for Developing Countries. National Washington DC. Academy Press.

Chospa, K. et al. 1990. Participatory Development: People and common property resources. Sage Publications, New Delhi.

Coleman, J. 1988. Social capital in the creation of human capital. American Journal of Sociology, 94 (Supplement) : S 95\$210.

Jentoff, S. AND T. KRISTOFERSEN 1989. fishermen's Co-management: The case of the Lofoten fishery. Human organization, 48 (4) : 355-364.

Kadappuram, J. F. 1989. People's Technology in Fisheries, India. (Paper presented at the ITDG International Seminar, London).

KURIEN, JOHN 1987. "Knowledge systems and fishery resources decline : A historical Perspective". In : W. LENZ ANO M. DEACON (Ed.) Ocean Sciences: Their history and relatin to man. (Proceedings of the IV History of Oceanography Congress). Deutsche Hydrographische Hamburg : Zeitschrift.

1992. Runing the commons and responses of the commeners: Coastal overfishing and fishworkers' actions in Kerala State, India. In : D. Ghal and J. M. VIvian (Ed.) Grassroots environmental action: People's participation in Sustainable Development. Routledge, London.

Netring, R. McC. 1981. Balancing on an Alp. Cambridge University Press, Cambridge.

NorgaARo, R. B. 1984. Coevolutionary development potential. Land Economics, 60 (2) : 160-173

Ostrom, E. 1990. Governing the commons: The evolution of Institutions for collective action. Cambridge University Press, Cambridge

SHeEny, D. J. 1982. New approaches in artificial reef design and applications. Aquabia Inc., Annapolis.

SIY, R. J. 1982. Community resource management : Lessons from the Zanjera. University of Philippines Press, Quezon Ciry. 